\title{
Occupational Segregation of Work and Income Disparities among South African Women
}

\section{P Lalthapersad}

Department of Economics, Vista University

\section{ABSTRACT}

Despite the increase in the number of women participating in the South African labour market in recent years, little progress has been made in removing wage disparities, eradicating women's marginality in the labour market, reassessing women's work or changing the traditional occupational ghettos of women. Not only does the South African labour market exhibit anomalies in respect of the gender composition of occupations, there are substantial differences by race. A good barometer of determining the extent to which men and women undertake different types of jobs, is to analyse the percentage of male and female workers per occupational category.

JEL $\mathbf{J 1 6}$

\section{INTRODUCTION}

The primary objective of this article is to examine gender segregation of occupations and the implications thereof on remuneration and income levels. The principles of patriarchy and sexism impinge on women's role in society, in the household and in the labour market. There are stark differences in the nature and scope of male and female labour force participation. Whilst male participation in the labour force is contrived on the absence of domestic and childcare responsibilities, women bear the brunt of unpaid work in the home. Women's responsibility for familial tasks negatively impacts on their economic status. A further factor that impairs women's labour market status is the structure of labour markets. Research by Barron and Norris (1976: 64) on dualism in labour markets revealed that the primary sector which offers socalled 'good' jobs, is male oriented, whilst the secondary sector which comprises 'mediocre' jobs, is female oriented. Even the occupational structure reveals a strong gender bias, in that males dominate managerial, professional and technical posts. Blue collar work is primarily reserved for men, and white collar work is for women. Moreover, the gender segregation of occupations is complicated by a vertical dimension within occupations, that causes men and women to be hired at different levels. This phenomenon is clearly 
distinguishable in the managerial vocation where men hold the executive positions or regional managerial posts, whilst women are likely to be administrative and departmental managers. Such a rigid occupational structure along gender lines translates into economic inequality. To acquire a more comprehensive understanding of the influence of gender parameters on the labour market, gender-sensitive indicators that compare the situations of males and females to expose relative inequalities, are used. To lay the groundwork for such an analysis, we begin by examining the results of the South African Enterprise Labour Flexibility Survey undertaken by the International Labour Office in South Africa in 1995 (Standing et al., 1996: 339-345). This is supplemented by a 1998 empirical study of the sexual composition of staff in manufacturing and retailing firms. Lastly, to gauge the extent of occupational segregation and income disparities between racial groups, a segregation index will be applied to the 1996 South African Population Census (Census in Brief, 1996).

\section{REASONS FOR OCCUPATIONAL SEGREGATION}

A marked feature of most workplaces, industries, occupations and jobs is that they are clearly segregated along gender lines (Reskin, 1984: 1). Reasons for women's concentration in a limited number of occupations are varied and range from the view that women chose to adhere to certain occupations to the deliberatel decisions to acquire less human capital. Also, responsibility for familial duties may be another factor that perpetuates occupational segregation. Economic explanations for occupational segregation identify discrimination as a cause of wage inequality ( $o p$ cit.: 5). More general theories of discrimination expound the role of "taste for discrimination", the actuality of overcrowding, monopsony in the labour market, statistical discrimination on the part of employers and dualism of the labour market as key elements that actuate inequality in the labour market (Reskin, 1984: 2).

According to Reskin (1984: 3) the segregation and gendering of work can be characterised in three ways:

- First, social engineering may push certain sexes into different ambits of society, that is, women into the private (or domestic) sphere, and men into the public sphere;

- Second, certain industries and occupations tend to be dominated by one gender, for example, the construction industry and managerial occupations are filled by men, and sales and clerical work by women; and

- Third, work is functionally segregated, that is, men and women perform different types of jobs within the same work setting. Women's jobs are usually subsidiary and peripheral to the mainstream jobs undertaken by 
men. Diversification of jobs generates conditions that are unique in terms of authority structures, pay rates and the provision of training opportunities. Such a stratification of work hinders movement between hierarchies and confines women to the lower echelons.

There is no simple dichotomy between male and female occupations but rather an amplitude of differences between and within both occupational categories and industries. The segmentation of jobs in terms of educational criteria, skills acquired, ability to operate apparatus or perform a designated function, generates jobs that are deemed suitable for a particular gender. Typically, female occupations contain fewer promotion opportunities and have many ports of entry in comparison to male jobs. Female workers are further differentiated in terms of age, education and marital status (Beechy \& Perkins, 1987: 134).

\section{JOB SEGREGATION AND PAY DIFFERENTIALS}

Since men and women perform different types of work, a wage differential develops between the sexes. A gender-stratified occupational structure shores up earnings inequalities and denies women economic parity. Studies indicate that there is an inverse relationship between remuneration and the percentage of women in an occupation, holding constant factors such as the length of the workday (Beller, 1984: 11). Reskin (1984: 4) contends that "the more "female" an occupation, the less it typically pays'. A major consequence of lower eamings for women is that both women and their families become more susceptible to lower standards of living and general poverty.

Two models attempt to explain lower wages for women. The exclusion model argues that women are excluded from higher-paying jobs and hired to fill lower-paying ones. This model assumes that pay rates are independent of market forces. The crowding model argues that women are consistently excluded from desirable jobs and crowded into undesirable ones. In this case, market forces ultimately determine wage rates. However, a bloated supply of female labour pushes down wages in desirable jobs (Jacobsen, 1986: 242).

A person's labour market position does not only determine a person's wage rate, but also reflects the value that both employers and societies attach to the worker's output. Wage levels measure the income that the individual earns for consumption purposes, and ultimately her standard of living. The problem with income inequality is that it tends to become more pronounced over time, thereby complicating its future circumvention. Also, low rates of pay for the jobs women perform cannot be easily corrected, as most firms tend to adopt existing norms in deciding their remuneration packages. 


\section{RESULTS OF ILO SURVEY}

The South African Enterprise Labour Flexibility Survey of 1995 (Standing et al., 1996: 339-45) of 354 manufacturing firms, aimed to provide information on the employment and hiring practices of firms. Regarding the effect of gender in hiring, the survey found the following:

- $\quad 52.1$ per cent of all firms opted for male production workers; and

- 6.6 per cent of all firms in general were recruiting black women (op cit.: 339 ).

Employers that reported a preference for men for production jobs based their argument on 'physical strength' (op cit.: 392).

The survey showed that occupational segregation in manufacturing was rife as men tended to occupy mostly managerial, the highly skilled and supervisory positions. On the other hand, very few women occupied senior positions ( $o p$ cit: 407 ). The sectoral distribution of women workers revealed a low share of employment in all sectors, namely:

- 70 per cent in textiles and garments;

- 28 per cent in paper and printing;

- 22 per cent in chemicals;

- 21 per cent in food processing;

- 15 per cent in metals and engineering;

- 14 per cent other.

Women were virtually excluded from apprenticeships due to the fact that they accounted for a negligible portion of employment in all sectors, except the textile and garment industry. Food processing plants employed no female apprentices. Both the paper and printing sectors and the metal engineering sectors employed few female apprentices, namely 2.4 per cent and 3.5 per cent respectively. Only the textile and garment industries boasted a large proportion of female apprentices (that is, 58.6 per cent) (op cit.: 402). The small number of female apprentices could be attributed to the fact that employers became reluctant to appoint apprentices during the 1990 s as the tax incentive on apprenticeships was removed. Another reason for this trend is that employers began to utilise less skilled workers to carry out the routine parts of an artisan's job, leaving the parts requiring more skills to the technicians. Statistical discrimination regarding women's work ethic also negatively impacted on the hiring of female apprentices (Department of Labour, 2000: 14).

Training opportunities for women were scant, with only 23 per cent of women having access to training opportunities. Many employers also reported a preference for allocating training opportunities to men and the accessibility of 
training for women varied directly with the female share of the workforce (op. cit: : 407). The allocation of training opportunities could be viewed as a means of reinforcing gender-based, sectoral segregation of employment.

\section{EMPLOYMENT TRENDS IN MANUFACTURING AND RETAILING INDUSTRIES}

A survey of manufacturing and retail industries was undertaken in 1998 and aimed to determine the distribution of men and women, irrespective of race, across the occupational hierarchy (Lalthapersad, 1998). Respondents were asked to provide information on the distribution of males and females, irrespective of race, in terms of the 9 broad categories of occupations as stipulated by the Standard Classification of Occupations (SCO).

Three hundred questionnaires were mailed to retailing and manufacturing firms in the Gauteng area. The industrial registrar of the Bureau of Market Research (BMR) served as basis for choosing the sample. In manufacturing, only those firms with a staff complement of more than a hundred were considered whilst in retailing enterprises, a complement exceeding thirty was required. 265 questionnaires were received which gives a response rate of 88 per cent.

In analysing all data, T-tests were performed to establish whether differences between the scores were statistically significant. An important consideration in the selection of level of significance is the total number of statistical tests to be performed. As the total number of tests increases, the probability of a type-I error also increases. One approach to counter this accumulating effect, is to reduce the level of significance for the individual statistical test so as to compensate for the overall type-I effect (Winer, 1971: 14-15). In this study, statistics were performed mostly on an item level. In order to achieve a reasonable protection against type-I error, a level of 0.005 was selected.

In the following section, the results of this study are discussed. Figure 1 below, details the occupational distribution in manufacturing industries. 


\section{Figure 1 Percentage of men and women per occupational group in manufacturing industries, 1998}

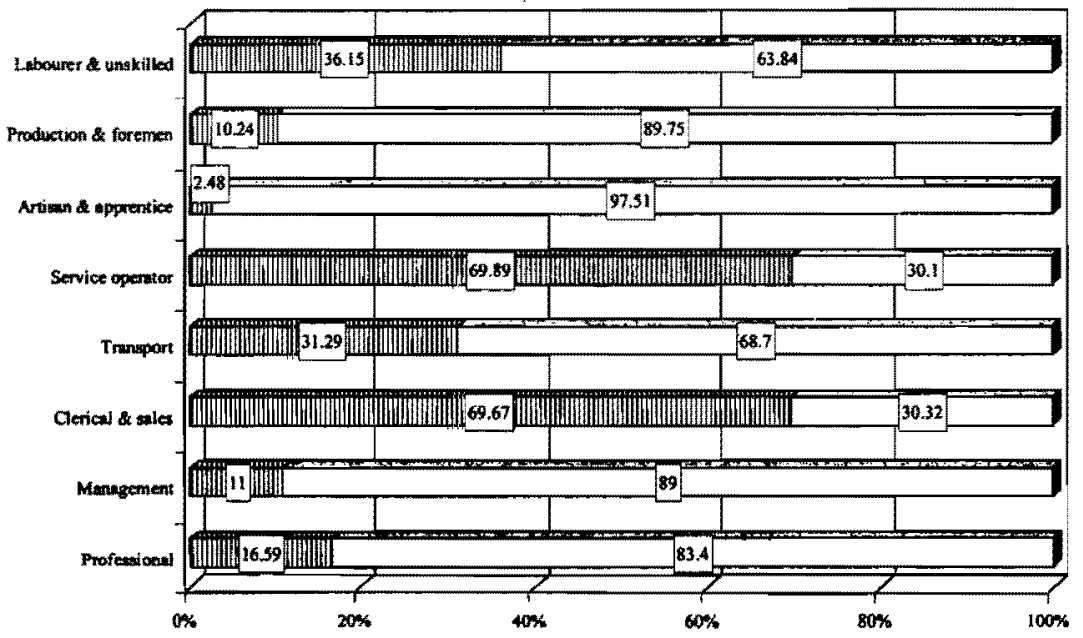

mWamen DMen

In manufacturing industry, extremely high proportions of men occupied the following job categories:

- $\quad$ production and foreman (89.7 per cent);

- $\quad$ artisan and apprentice ( 97.5 per cent);

- $\quad$ management (89 per cent); and

- $\quad$ professional (83.4 per cent) (Lalthapersad, 1998).

Also, a higher percentage of males (63.8 per cent) performed unskilled work compared to females ( 36.1 per cent). Women workers were located mainly in the service occupations (69.9 per cent) and clerical and sales (69.8 per cent). The proportion of female artisans and apprentices were marginal (i.e. 2.4 per cent) (Lalthapersad, 1998: unpublished Phd thesis).

Figure 2 displays the results for retail trade. 
Figure 2 Percentage of men and women per occupational group in retail trade, 1998

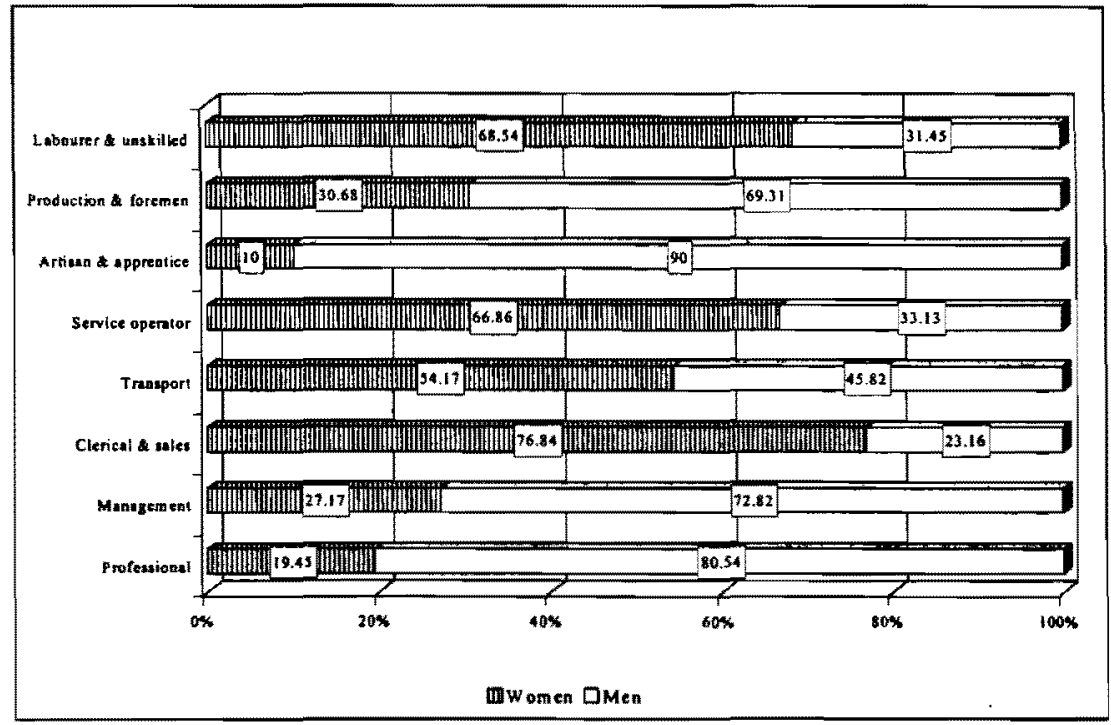

In retailing, the following results were noteworthy:

- Males abounded in four occupational categories, namely, production and foremen (69 per cent), artisan and apprentice ( 90 per cent), management (72 per cent) and professional ( 80 per cent);

- Females prevailed in three occupational categories, namely, service sectors (67 per cent), unskilled ( 69 per cent) and clerical and sales ( 77 per cent); and

- Comparing the retail and manufacturing, it is apparent that the number of females in the categories of professional (19 per cent) and especially management ( 27 per cent) is substantially higher in retailing (Jacobsen, 1986: 56) and (Lalthapersad, 1998).

Higher numbers of females in managerial positions in retailing industry could be attributed to factors such as the magnitude of such enterprises and an evidently large contingent of female workers. The segregation of jobs is extremely marked as evidenced by the distribution of males and females between occupations. The professional, managerial, production worker, artisans and apprentice categories are overwhelmingly male in both industries. On the other hand, the sales, clerical and service occupations are primarily female. This situation complies with duality in the labour market, namely, whilst the primary sector is essentially male, the secondary sector is exclusively female. 
The low proportion of women in managerial, technical and professional occupations, is a crude indicator of women's share of decision-making positions in the economy. Furthermore, the jobs women perform are an extension of the caring they provide in the home. The nature of clerical work is such that it can be easily deskilled through the application of microelectronic technology. Such an actuality would inflict major job losses among female workers.

\section{SOUTH AFRICAN STATISTICAL DATA}

Limited research has been done on the employment and economic sectors of women in South Africa. Therefore, there is limited statistics and no reliable data base on wage and employment trends. Information on wages and other aspects of remuneration such as fringe benefits is also flawed. Figures on many aspects of women's activities are non-existent (Standing et al., 1996: 7). Also, over the years, a change in the compilation of employment figures has rendered comparative analysis difficult. In fact, the ILO has wamed that all data before 1994 be examined cautiously. In light of this, the only major and reliable source of data on the South African labour force, remains the 1996 South African Population Census data. Hence, the 1996 South African Census Data was utilised to apply the segregation index.

\section{SEGREGATION INDEX VALUES}

The extent of occupational segregation can be measured using the index of segregation. The segregation index attempts to estimate the overall level of segregation. The Duncan Index of Dissimilarity can be used to measure segregation for an array of variables (Beller, 1984: 11).

The index is calculated as:

$100 \times \sum_{i=1}^{N} \frac{\left(\frac{X i}{X}-\frac{Y i}{Y}\right)}{2}$

where: $\quad N=$ the number of occupations

$X_{i}=$ the number of persons of a group in occupation $i$

$X=$ the total number of persons in this group

$\mathrm{Y}_{i}=$ the total number of persons in a comparison group in occupation $\mathrm{i}$

$\mathrm{Y}=$ the total number of persons in the comparison group. 
The index ranges from zero (complete integration) to 100 (complete segregation). The index value is influenced by the degree of aggregation of occupations. The fewer the occupational categories, that is, if occupations are lumped together, the smaller the value of the index (Beller, 1984: 12). In the case of South Africa, there are only 10 broad occupational categories such that segregation values are low. Table 1 was derived from the 1996 South African Population Census data and displays the index value per occupational group for the total South African labour force, irrespective of race.

\section{Table 1 Gender index values per occupational group}

\begin{tabular}{|l|c|}
\hline \multicolumn{1}{|c|}{ Occupation } & $\%$ \\
\hline Legislators & 45.5 \\
\hline Professionals & 10 \\
\hline Technicians & 4 \\
\hline Clerks & 38 \\
\hline Service workers & 30 \\
\hline Skilled agriculture & 59 \\
\hline Craft workers & 74 \\
\hline Plant assemblers & 68.5 \\
\hline Elementary & 42.5 \\
\hline Unspecified/ other & 42 \\
\hline
\end{tabular}

Source: Own

Four occupational categories appear to be highly segregated, that is:

- legislators (45.5 per cent);

- $\quad$ skilled agriculture (59 per cent);

- craft workers (74 per cent); and

- plant assemblers (68.5 per cent).

The latter three occupations are manual in nature, physically demanding and tend to employ mostly men. The low proportion of women in the above occupations is exacerbated by the fact that women tend to be denied apprenticeship and training opportunities and are thereby excluded from such occupations. A lack of access to technical education may also be a compounding factor.

Three occupational categories have intermediate levels of segregation, which categories are:

- unspecified/other which includes informal sector work and domestic work 
(42 per cent);

- $\quad$ clerks ( 38 per cent); and

- $\quad$ service workers ( 30 per cent).

Two occupational groups exhibit high integration, namely:

- professionals ( 10 per cent); and

- technicians (4 per cent).

The reason for the professional group being highly integrated is that most matriculated black women opted for the nursing and teaching professions as these were the only well-paying occupations open to them. The high number of female technicians results from the fact that many white women qualified as technicians since they benefited from a well developed educational system under the policy of separate development.

In Table 2, the income levels of males and females of each population group are assessed against their respective group.

Table 2 Gender index per income level

\begin{tabular}{|l|c|c|c|c|}
\hline Income level & \% Black & \% Coloured & \% Indian & \% White \\
\hline R3501+ & 0.8 & 4.5 & 13.1 & 29.4 \\
\hline R1501- R3500 & 6.8 & 6 & 6 & 17.5 \\
\hline R1001 - R1500 & 11.3 & 0.9 & 7.7 & 4.7 \\
\hline R501 - R1000 & 3 & 0.9 & 7.2 & 3 \\
\hline R0 - R500 & 21.7 & 10.6 & 4.1 & 3.7 \\
\hline
\end{tabular}

Source: Own

For the white population, the index value is highest for the two top income levels due to the previous preferential treatment of white males under the apartheid system. The two top incomes' bracket cumulatively, accounts for more than a third of all white workers, and compares disproportionately with the other race groups, namely, Black ( 7.6 per cent), Coloured (5.1 per cent) and Indian (13.7 per cent).

For the Black population, an index value of 0.8 per cent for the highest income level implies complete integration of both sexes. Such a result is encouraging for two reasons. First, Black men and women have only recently started to acquire jobs previously denied to them. Second, Black workers have embarked on occupational mobility. Furthermore, the result is encouraging because even though Black women comprise a smaller portion of the labour force, they have 
attained income parity with Black men. There is quite a high level of integration for the income bracket R501-R1001. But segregation is relatively high for the R0-R500 income bracket. The latter situation is due to high unemployment rates among both black men and women. For the coloured population, there is intermediate segregation in the top income bracket and low segregation for the income level's R1001-R1500 and R501-R1001. Relatively high segregation occurs in the lowest income group of R0-R500. The Coloured population, like the other two non-white groups were subjected to artificial restrictions in the labour market and tended to occupy mainly secondary sector jobs.

For the Indian population, segregation in the top income category is high due to the low number of women participating in the labour market. However, the remaining income brackets exhibit a greater degree of integration.

\section{CONCLUSION}

Intra-occupational segregation (that is, the concentration of men and women in certain occupations) is an indelible feature of most labour markets. The influence of gender is pervasive in occupational categorisation, that is, some jobs are principally male or outrightly female. This difference in the occupational structure invariably precipitates income inequality, a skewed distribution of fringe benefits and amplifies economic inequality between men and women. Women's poverty is the inevitable result of their disadvantaged position in the labour market. Women's vulnerability resides in their monopolisation of the service and retail sectors, sectors that are susceptible to retrenchment and downsizing in recessionary periods. According to Bhorat (2001: 35) since 1994, 140000 female jobs were lost and black women alone accounted for 118703 of the said job losses. Hence occupational stratification could be largely responsible for the socioeconomic gap between the sexes. A rigid occupational segregation, also impinges on the future occupational structure as sex-tying of jobs becomes more entrenched.

To break this convention, women have to be imbued with the necessary support structures and training opportunities to enable them to filter into non-traditional jobs that remunerate fittingly. Government has already taken the initiative by legislating the Employment Equity Act in 1998, which seeks specifically to advance women by prohibiting discrimination on the grounds of gender and endorsing affirmative action measures to remedy past imbalances in the labour market. To support companies to reach their employment equity targets, government has passed the Skills Development Act and the Skills Development Levies Act, which aims to provide previously disadvantaged groups, such as Blacks and women, with the necessary skills to enhance their employability. In 
light of the AIDS pandemic that is expected to reduce the labour force quite drastically, occupational separation will prove to be ineffectual and will be tantamount to a loss of much needed human resources.

\section{REFERENCES}

1 BARRON, R.D. \& NORRIS, G.M. (1976) "Sexual Divisions and the Dual Labour Market", in Barker,D.L. and Allen, S. (eds.) Dependence and Exploitation in Work and Marriage, London: Longman.

2 BEECHEY, V. \& PERKINS, T. (1987) A Matter of Hours, Cambridge: Pluto Press.

3 BELLER, A.H. (1984) "Trends in Occupational Segregation in the Workplace", in Reskin, B.F. (ed.) Sex Segregation in the Workplace, Washington: National Academy Press.

4 BHORAT, H. (2001) "Explaining Trends in South Africa 1993-1998", in New Agenda, 4: 21 -38.

5 DEPARTMENT OF LABOUR (2000) The National Skills Development Strategy, Pretoria

6 JACOBSEN, J.P. (1986) The Economics of Gender, Massachusetts: Blackwell Publishers.

7 LALTHAPERSAD, P. (1998) "The Casualization of Black Female Labour in South Africa," Unpublished PhD thesis, Vista University, Pretoria.

8 RESKIN, B.F (1984) Sex Segregation in the Workplace: Trends, Explanations and Remedies. Washington: National Academy Press.

9 STATISTICS SOUTH AFRICA (1998) Census in Brief. Report no. 1-0301-11, SSA: Pretoria.

10 STANDING, G.; SENDER, J. \& WEEKS, J (1996) Restructuring the South African Labour Market -The South African Challenge, Geneva: ILO Office.

11 WINER, B.J. (1971) Statistical Principles in Experimental Design, Tokyo. McGraw-Hill. 